I hoped to discuss some of the experiences of myself, colleagues and patients, as we are presently unable to do in this country, to gain the understanding and advice of our colleagues in Britain, and to present new information of potentially significant value in other countries.

When I arrived in Britain for the meeting, I received a very curiously worded letter from the President, telling me that my two papers had been withdrawn from the programme, and I was not to talk at the College meeting.

No proper explanation of this extraordinary and unethical behaviour has ever been given to me. Reference was made to a recent College resolution: yet that resolution specifically and expressly insisted that NO academic boycott should occur, and that Members and speakers from South Africa should NOT be barred from speaking at College meetings. Though that resolution was properly passed by the formal processes of the College after due discussion, and should be binding on the President and officers of the College, they acted in direct contravention of its meaning and intent.

This was, I believe, the first time that a British Royal College has excluded one of its senior members from participation in a meeting, for base political reasons. It is unethical and improper action, even in breach of basic Hippocratic rather than hippocritic principles.

No public announcement was ever made about this cowardly act, and members were never told what their President and College had done. People were widely puzzled about why I never appeared at the podium to speak; and my professional and academic reputation (as a significant speaker, who has never yet failed to attend and speak when expected) was damaged.

My feelings were ignored. Apart from shifty, muttered, embarrassed, brief comments by some of those responsible for what happened, I never received a proper apology or the chance to discuss the situation.

Since my return, I have received many messages of support from all sections of our people, who have asked me to convey to you their disgust at the way I was treated. Representatives of noted major democratic organisations of South Africa have assured me that no one in any way authorised to speak on behalf of any respectable South African representative group approached the College to have my invitation withdrawn: rather, they would want me to have been heard.

We are concerned as to the true source of the pressures to which the College gave in, to prevent any chance of critical discussion of mental health problems in South Africa. We note that the College has given hospitality to proGovernment Professors of Psychiatry from South Africa: though such contacts are more likely to be in breach of the College's recent resolution, as by such means support and encouragement is given to those responsible for providing seriously sub-standard psychiatric and medical care to the majority of our people.

We note that several senior Fellows of the College have had no scruples whatsoever about earning generous honoraria from drug companies for visiting South Africa, often repeatedly, and giving largely undistinguished presentations of information already readily available to us, and usually irrelevant to our real professional problems. Those in the College concerned with censoring me, in their shabby exercise in academic apartheid, should take more interest in such visits.

What the College did was to shamelessly surrender to a tiny group who titillate themselves by meddling in affairs they do not understand, in victimising the victims, in their self-glorifying roles as self-appointed spokesmen for those they never listen to.

I write because I believe that an indiscriminate, decerebrate, academic boycott such as the College exercised is immoral, professionally unethical, and an unwarranted threat to the health and well-being of already underprivileged people. I do not accept that the President was right to act as he did, or to try to sneak through such a dishonourable breach of formal College policy, behind the scenes, without proper debate by the Membership, to whom he is answerable.

I look forward to being enabled to address the College properly at a major College meeting at some early opportunity. Perhaps, though, my address on such an occasion could include the material the President banned me from presenting in 1987; it could be a more formal presentation on issues of academic freedom, and the responsibility of psychiatrists in situations such as ours.

Michael A. Simpson

PO Box 51

Pretoria 0001, South Africa

\section{Dr Birley replies}

I understand Professor Simpson's indignation at the withdrawal of his two papers, and I am sorry that he felt that my attempts at explanation, in my "curiously worded letter" and in our conversations, were inadequate.

The interpretation of our Council Resolution is clearly a matter for debate, but the views expressed to me, in protest at Professor Simpson's speaking, were strong and articulate and from a wide variety of well-informed sources. They felt that a speaker from an apartheid university was not acceptable and would give an unfortunate impression to the ethnic minorities in this country who already view psychiatry with some alarm and suspicion.

Professor Simpson does not mention that the original invitation from the College was for him to have the opportunity to speak about his experiences to the College's Unethical Practices Committee. This Committee heard from Dr Koryagin in the morning and, after lunch, when both were our guests, we heard from Professor Simpson.

DR J. L. T. BIRLEY

President

\section{Estimating hospital bed numbers \\ DeAr Sirs}

I am afraid that Dr Marjot's letter on Estimating Hospital Bed Numbers (Bulletin, December 1987) contains an error which renders his conclusions invalid. 